\title{
Banking Sector Reforms and the Performance of Commercial Banks in Nigeria
}

\author{
Uduak M. Ekong, Ubong E. Udonwa \\ Department of Economics, Faculty of Social Sciences, University of Uyo, Uyo, Nigeria
}

Email address:

wills4live@yahoo.com (U. M. Ekong)

To cite this article:

Uduak M. Ekong, Ubong E. Udonwa. Banking Sector Reforms and the Performance of Commercial Banks in Nigeria. Journal of World Economic Research. Vol. 4, No. 3, 2015, pp. 45-60. doi: 10.11648/j.jwer.20150403.11

\begin{abstract}
The study investigated the performance of Commercial Banks in Nigeria after Banking Sector Reforms. In order to be thorough, the performance of Commercial banks before the Reforms was also investigated. Here we analyze the relationship using Error Correction Mechanism and Chow test over the period 1970-2012. The Variables used were obtained from the banking system. The study found out that the reforms brought about some important changes in Commercial Banks Performance in Nigeria. Specifically, the level of profit (measured by NIM) continues to improve above single digit of 9.17 in 1996 to 16.18 in 2004 and a peak of 20.96 in 2011 . This translates into a mean profit of 2.40 recorded in the deregulated period as against 1.54 recorded in the regulated period. Commercial Banks may improve in performance in terms of profitability, but may not really impact on the real economy at least on the short run. The study also shows that much of the benefits to commercial banks in credit creation in the economy will be derived at a price of time. A number of possible policy menu capable of bringing about a sustained Commercial Banks Performance in Nigeria in years following the study have been prescribed in the study.
\end{abstract}

Keywords: Commercial Bank Performance, Profitability, Net Interest Margin, Baking Sector Reforms, Nigeria

\section{Background Information}

Banking Sector Reforms have been a regular feature in the Nigerian financial system, conducted mainly to improve the performance of commercial banks on the one hand and to improve the effectiveness and efficiency of the banking system and the economy in general.

In fact, if we follow Nzotta and Okereke (2009), reforms in the banking system date back to 1952 when the Banking Ordinance was enacted. At some instances, much of the reforms centered on capital requirement for start-up. For instance, since the inception of banking regulation in Nigeria, there has always been a directive issued from time to time by the regulatory authorities on the minimum paid-up capital required before a bank can be licensed to operate. The stipulated minimum paid-up capital requirements over the years have witnessed a steady growth since the first Nigeria banking law was passed in 1952.The 1952 banking ordinance stipulated a minimum capital of $\mathrm{N} 25,000$ for indigenous and $\mathrm{N} 200,000$ for expatriate commercial banks. This rose to N600,000 and N1.05 million for indigenous and expatriate banks respectively by the 1962 act.
During the period 1959-1985, several important legislations were enacted aimed at promoting and integrating the Nigerian financial system. The era began with the enactment of the central bank of Nigeria Act of 1959. In 1969 the banking Act was Enacted. The period also witnessed several regulating measures taken by the government. Between 1970 and 1977 government took two important measures. These were the indigenization promotion decree of 1972, amended in 1977 that gave the government the acquisition of controlling interest in the then existing foreign banks $(40 \%)$, and the establishment of a financial system review committee in 1976 to review the whole financial system in other to strengthen the efficiency of the financial system (the Okigbo Committee of 1976). As a means of strengthening the banking sector and accelerating economic development, government established the Nigerian Agricultural and Cooperative Banks, the Nigeria Bank for Commerce and Industry and reconstituted the Nigeria Building Society as the Federal Mortgage Bank of Nigeria. This was followed by establishing state Commercial Banks 
and Development of finance companies. The reforms have evolved in response to the challenges posed by development in the system such as systemic crisis, globalization, technological innovations and financial crisis.

Ofanson, Aigbokhaevbolo \& Enabulu (2010), described the period as the period guided by the passion for selfreliance. The government, through her agency- the Central Bank fixed prices of financial products, directed where and how the resources of the sector should go and be used. This sometimes, saw the resources of the sector being channeled to ventures that might not be socially optimal, and the system performing poorly. However from 1986 to date, the banking sector has witnessed reforms aimed at freeing the sector's resources to where returns will be maximum. According to Balogun, (2007), we recognize four phases of banking sector reforms since the commencement of SAP. The first is the financial systems reforms of 1986 to 1993 which led to deregulation of the banking industry that hitherto was dominated by indigenized banks that had over 60 per cent
Federal and State governments' stakes, in addition to credit, interest rate and foreign exchange policy reforms. The second phase began in the late 1993-1998, with the re-introduction of regulations. During this period, the banking sector suffered deep financial distress which necessitated another round of reforms, designed to manage the distress. The third phase began with the advent of civilian democracy in 1999 which saw the return to liberalization of the financial sectors, accompanied with the adoption of distress resolution programmes. This era also saw the introduction of universal banking which empowered the banks to operate in all aspect of retail banking and non-bank financial markets. The fourth phase began in 2004 to date and it is informed by the Nigerian monetary authorities who asserted that the financial system was characterized by structural and operational weaknesses and that their catalytic role in promoting private sector led growth could be further enhanced through a more pragmatic reform. The various reforms of the sector over the period are shown in Table 1.1.

Table 1.1. Chronology of Major Banking Sector Reforms in Nigeria

\begin{tabular}{|c|c|c|c|}
\hline $\mathbf{S} / \mathbf{N}$ & Banking Sector Reform Event & Measures Adopted & Year \\
\hline 1 & Promulgation of Indigenization decree (amended 1977) & Direct Participation & 1972 \\
\hline 2 & Deregulation of the lending and deposit rates (several reversals) & & 1987 \\
\hline 3 & Entry deregulation for banks (several reversals) & & 1987 \\
\hline 4 & Abrogation of sectoral credit allocation (partial) & & 1987 \\
\hline 5 & Foreign Exchange deregulation & & 1987 \\
\hline 6 & Creation of deposit Insurance scheme (NDIC) & & 1988 \\
\hline 7 & Review of minimum paid-up capital for banks (several increases to date) & & 1988 \\
\hline 8 & Withdrawal of public sector deposits from banks (several reversals) & & 1989 \\
\hline 9 & Creation of specialized banking institutions (peoples bank 1989; community banks 1990) & & 1989 \\
\hline 10 & Prudential Guidelines & & 1990 \\
\hline 11 & Partial Privatization of banks & & 1991 \\
\hline 12 & Reform of the regulatory/ supervisory framework (BOFID, CBN decree) & & 1991 \\
\hline 13 & Indirect monetary control & & 1993 \\
\hline 14 & Capital market reform ( partial in 1993) & & 1997 \\
\hline 15 & Re-entry of fully foreign owned banks & & 1999 \\
\hline 16 & Institutionalization of foreign currency deposits & & 2000 \\
\hline 17 & Universal banking evolved & & 2001 \\
\hline 18 & Bank Consolidation & Mergers/ Acquisition & 2004 \\
\hline 19 & Creation of asset management company (AMCON) & & 2010 \\
\hline
\end{tabular}

Source: Constructed by the Researcher based on information from Asogwa, (2005) and Ofanson, et al (2010)

From the table above, it can be seen that much of the changes in the sector was driven by indigenization decree of 1972. Pursuant to this decree, the government acquired controlling interest in the then existing three expatriate banks (First bank, Union bank, and United Bank for Africa); established Federal Government wholly owned banks (the Nigerian Agricultural and Cooperative Bank, the Nigerian Bank for Commerce and Industry, and reconstituted Nigerian Building Society into the Federal Mortgage Bank; established the State Government wholly owned banks and directly controled the allocation of credit to prioritize areas such as manufacturing, agriculture and even imports.

Following SAP, the banking systems' deposit and lending rates were deregulated in august 1987 with the aim of sustaining efficient allocation of financial resources. The central bank then first adopted a system of fixing only the minimum rediscount rate to indicate the desired direction of interest rate changes (Asogwa, 2005). The essence of entry deregulation for banks in Nigeria was to enforced market competition. Before this time only three big banks- First bank, Union bank and United Bank for Africa dominated the banking business. It was therefore necessary to reduce concentration in the banking industry by only few cartels. By 1988, the Nigerian Deposit Insurance Corporation was established to strengthen the regulatory framework of banks as well as insuring deposit liabilities of the banking public. Over time the Nigerian Deposit Insurance Corporation also involved in assisting the central bank in formulating banking policies and surveillance reports for bank supervision. The foreign exchange market reforms came into effect in 1986 when the second tier foreign exchange market functioned as an auction forum for the sale and purchase of foreign exchange (with full effect in 1987), aimed at maintaining a stable exchange rate for the naira. As at 2000, the public were 
fully allowed to receive foreign remittances in foreign currency in their own domiciliary accounts, aimed at retaining foreign savings in the banking system- apparently to address the foreign reserve position of the country to which the IMF/World Bank model had proposed. This reform measure witnessed several policy reversals (Kimera, 2011).

Since the inception of banking regulation in Nigeria, there has always been a directive issued from time to time by the regulatory authorities on the minimum paid-up capital required before a bank can be licensed to operate. The stipulated minimum paid-up capital requirements over the years have witnessed a steady growth since the first Nigeria banking law was passed in 1952. This was not the only time that Nigerian Banks were asked to shore up their capital base. From a modest value of N10million naira minimum paid-up capital in 1988, and following the provision of section 9 (2) of Bank and Other Financial Institution Decree (BOFID), Nigerian commercial banks were required to maintain capital not below N50 million in 1991. Between 1991 and 2005 subsequent increases have also been made ranging from N500 million in 1997; N1billion in 2001; N2billion in 2002 to N25 billion in 2005.

Prudential guidelines regarding adequate provision for bad and doubtful debts and loan classification, interest capitalization and capital adequacy and limits on loan concentration was put in place in 1990. This was aimed at mitigating the spread of bank failures and non performing loans. Basically, the guideline requires that all banks categorize their business portfolio into performing and nonperforming ones (Ekong and Ikot, 2012).

In 2004, the banking sector, following the National Economic Empowerment and Development Strategy (NEEDS) proposal, involved in bank consolidation to increase the asset base of Commercial Banks in terms of capital size and in the number of banks. This was achieved mainly through mergers and acquisition, the exercise saw that any bank operating in the system has a minimum paid up capital of twenty five billion naira. Since most banks have already been drawn in the ocean of bad debt and high non performing loan, the Asset Management Company of Nigeria (AMCON) was instituted in 2010 to mitigate the effect of lost loans (Ekong and Ikot, 2012).

The financial systems of most developing nations have come under stress as a result of the economic shocks of the 1980s. In response to this, the post- independence banking history of Nigeria contains a lot of structural policy reforms that were meant to reposition the sector for sound operations. But the period also witnessed high bank failure rate. In fact, poor performance of commercial banks in the Nigerian banking industry dates back to the early 30 s when a number of bank failures and bankruptcies were experienced. According to Isu (1991), the spate of banking failure in Nigeria in the 1920s, '30s and '40s led to the Paton Enquiry in 1948 and finally culminated in the Banking Ordinance of 1952, which essentially set standards and procedures for the conduct of banking with an eye on stemming the high incidence of bank failures in the country. At least in that period, the reasons for such trend can be seen - absence of formal banking legislation and regulatory agency, the rudimentary nature of the banking system, and poor management of the Nigerian banks to the systems' newness (CBN, 2005a). However, the recurrence of financial distress and bank failures in the 80s, specifically between 1989 and 1998 was of great intensity, both in scope and depth. During this period, confidence in the banking system waned considerably as not less than 45 banks were categorized as distressed, and 31 banks had been liquidated by the end of 1998. When the performance of commercial banks in Nigeria was considered using net interest margin, the result was not impressive for most of the years. For instance, Net Interest Margin (NIM) grows at a declining rate from $7.0 \%$ in 1972 to $2.0 \%$ in 1977 , from $7.0 \%$ in 1978 to $2.25 \%$ in $1985,15.1 \%$ in 1988 to $2.22 \%$ in $1992,24.26 \%$ in 2002 to $14.81 \%$ in 2007 , showing that all is not well with the banking system (see figure 1.1). This is not withstanding the continued widening rate between savings and lending.

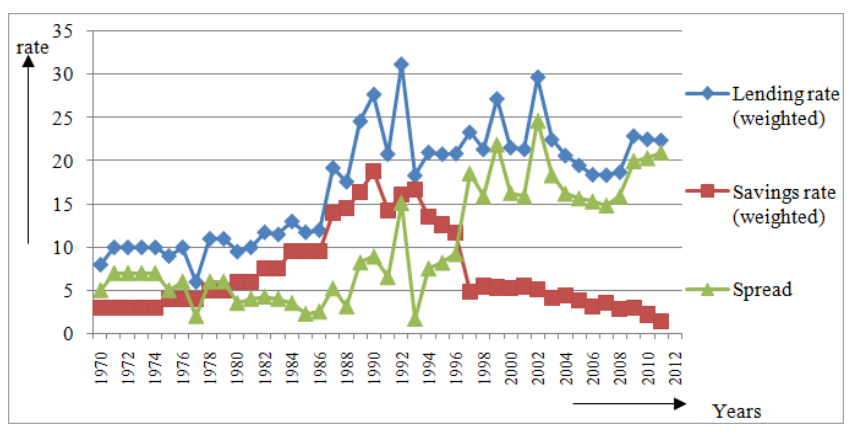

Source: Central Bank of Nigeria

Figure 1.1. Lending, Savings and Interest rate Spread in Nigeria (1970-2012)

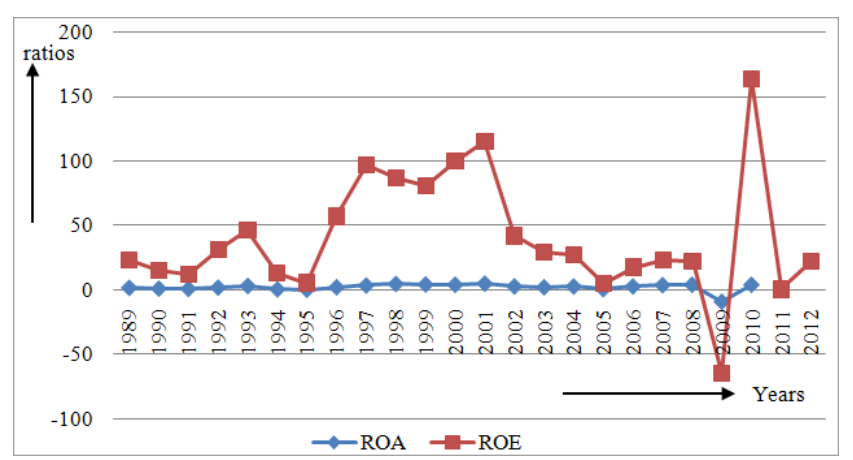

Source: Central Bank of Nigeria

Figure 1.2. Graph of Return on Assets and Return on Equity for the Nigerian Banking System (1989-2012)

A consideration of commercial bank performance in Nigeria using return on asset (ROA) and return on equity (ROE) exposes the sectors' weakness further. Particularly for 1989 and 2012, the performance indicators for the banking system shows that Commercial banks did not grow as expected over the period. Both ROA and ROE shows a downward trend for most of years (and negative in the other) (see figure 1.2). From 1.56 in 1989 , ROA falls to 0.92 in 1990 and 0.72 in 1991. Within the same period, ROE also 
fluctuates between 23.3, 14.7 and 12.2. Between 1993 and 1995, both ROA and ROE were 2.98, 0.33, 0.1 and 45.9, 12.62 and 5.27 respectively. Such trend was also noticed for ROE between 2001 and 2005, falling from 114.29 to 4.81 and a negative in 2009 (-64.72). All these suggest that all is not well for the commercial banking system.

Even in the $20^{\text {th }}$ century, the Nigerian banking system continued to witness pockets of poor performance sometimes necessitating acquisition or outright liquidation of some banks. The performance rating of commercial banking system in Nigeria as at 2001 to 2005 showed that the banking system was distressed, as marginal and unsound banks were on the increase (see table 1.2 and figure 1.3)

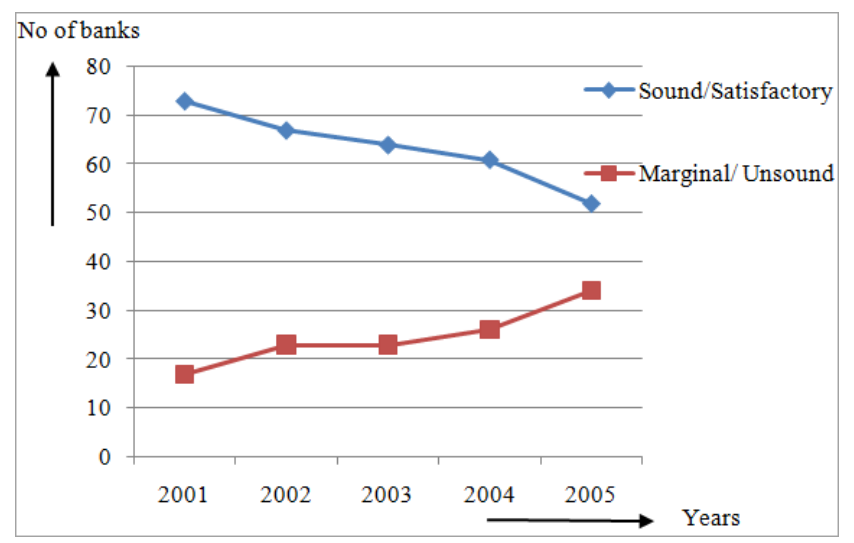

Source: CBN: A Case Study of Distressed Banks in Nigeria, 2005a.

Figure 1.3. Bank rating in Nigeria 2001-2005
Table 1.2. Bank rating in Nigeria

\begin{tabular}{lllllll}
\hline \multirow{2}{*}{ Category } & \multicolumn{9}{l}{ Number of Banks } & & & \\
\cline { 2 - 5 } & \multirow{2}{*}{$\mathbf{2 0 0 1}$} & $\mathbf{2 0 0 2}$ & \multirow{2}{*}{$\mathbf{2 0 0 4}$} & \multirow{2}{*}{$\mathbf{2 0 0 5}$} \\
\cline { 2 - 6 } & & Mid & End & & & \\
\hline Sound/satisfactory & 73 & 67 & & 64 & 61 & 52 \\
Marginal/unsound & 17 & 14 & 23 & 23 & 26 & 34 \\
\hline
\end{tabular}

Source: Researcher based on CBN: A Case Study of Distressed Banks in Nigeria, 2005a.

From table 1.2 and figure 1.3 , the symptoms of systemic distress which started in 2001 persisted with the number of sound and satisfactory banks declining steadily from 73 in 2001 to 52 in 2005 . By the end of 2002, about 23 banks were distressed. In the same vein, the number of banks that were marginal and unsound rose steadily from 17 in 2001 to 34 in 2005. The marginal /unsound banks exhibited such weaknesses as undercapitalization, weak and poor asset quality, poor earnings among others, such that the efficiency performance of banks continue to decline within the period from 4.73 and 55.81 percentage points on return on asset and return on equity in 2001 to 1.85 and 12.97 respectively in 2005 (see table 1.3).

Table 1.3. Efficiency of Nigerian Commercial Banks 2001 - 2005

\begin{tabular}{llllll}
\hline Efficiency Measures & $\mathbf{2 0 0 1}$ & $\mathbf{2 0 0 2}$ & $\mathbf{2 0 0 3}$ & $\mathbf{2 0 0 4}$ & $\mathbf{2 0 0 5}$ \\
\hline ROA & 4.73 & 3.47 & 2.67 & 3.12 & 1.85 \\
ROE & 55.81 & 36.60 & 25.52 & 27.35 & 12.97 \\
\hline
\end{tabular}

Source: CBN banking supervision annual report, 2005b.

The period 2008 - 2012 did not improve Commercial bank performance in Nigeria as Table 1.4 further indicates.

Table 1.4. Nigeria: Financial Sector Soundness Indicator

\begin{tabular}{|c|c|c|c|c|c|}
\hline Measures (growth rates) & 2008 & 2009 & 2010 & 2011 & 2012 \\
\hline Total Assets & 46.6 & -3.6 & -8.8 & 36.9 & -2.2 \\
\hline Total Loans & 62.3 & 0.2 & -10.8 & 21.3 & 5.4 \\
\hline Deposits & 65.0 & 18.4 & -11.3 & 30.2 & -1.6 \\
\hline Domestic banks & 119.3 & -69.7 & -25.8 & 20.2 & -47.8 \\
\hline Foreign banks & 61.9 & -18.3 & -3.0 & 41.5 & 10.3 \\
\hline NPL specific provision/ core capital & 9.1 & 106.8 & 192.7 & 9.4 & 5.1 \\
\hline \multicolumn{6}{|l|}{ Asset Quality } \\
\hline NPL/ Total Loans & 6.3 & 27.6 & 15.5 & 4.8 & 4.0 \\
\hline Specific provision NPL & - & - & - & 55.5 & 67.9 \\
\hline \multicolumn{6}{|l|}{ Earnings/ Profitability } \\
\hline Return on Average Asset & 3.7 & -8.9 & 3.0 & -0.1 & 1.2 \\
\hline Net Interest Margin & - & - & 6.0 & 4.5 & 3.2 \\
\hline \multicolumn{6}{|l|}{ Liquidity } \\
\hline Liquid Asset/ Total Assets & 17.6 & 16.5 & 17.2 & 25.7 & 39.0 \\
\hline Liquid Asset/ Total Deposits & 52.9 & 36.5 & 39.2 & 58.9 & 56.5 \\
\hline Loans/ Total Deposits & 66.6 & 56.4 & 56.6 & 52.8 & 56.5 \\
\hline
\end{tabular}

Source: IMF, Nigeria Financial Sector Stability Assessment, 2013

According to the assessment released by IMF in 2013, the growth rate of assets in the system was almost negative for all the five years. Growth rate of total asset fall from 46.6 in 2008 to -8.8 in 2010 and -2.2 in 2012 . The deposit drive in 
the period, especially from the domestic economy was poor. From the growth rate of 119.3 in 2008 , the rate decline sharply to -67.7 in $2009,-25.8$ in 2010 and -47.8 in 2012. The non performing loan of the system worsened from a more improved state of 6.3 percent in 2008 to 15.5 in 2010 until AMCON intervention in 2010 that bought up this debt burden on the system, producing a favourable 4.8 and 4.0 percent NPL ratio in 2011 - 2012 period -even better than the 5 percent NPL ratio that is accepted for a good banking system globally. Even when this happen, it was still noticed that the non performing loan to specific sectors of the economy continues to grow steadily from 55.5 to 67.9 percents between 2011 and 2012 and may impact negatively in the near future if not check. Earnings and profitability should definitely decline in such a trend. It was not surprised that return on average asset fell from 3.7 in 2008 to 1.2 in 2012; return on average equity fell from 20.7 to 8.9 within the same period; and net interest margin also fell from 6.0 in2010 to 3.2 in 2012. Infact, available records show that in 2011 alone, eight banks had negative profitability of the twenty that were in operation.

These arguments show that commercial banks' operations are still weak in Nigeria in-spite of the massive economic reforms taking place in the country necessitating the following questions:

1. How did Banking Sector reforms affect Commercial banks performance in Nigeria over the period under study?

2. In which period (Pre or Post reform) did Commercial banks in Nigeria performed better?

The study is significant, in that, it is expected to highlight the impact of Banking Sector Reforms on banking sector development, identifying possibly the reform regime in which the economy benefited more, as well as pointing out the cost of reforms switch. This will enable readers of interest and policy makers to know whether the sector is growing and adding value to the economy. Again, at the level of global economic development (particularly with the recent global financial crisis at heart), where efforts are being made to reposition the global financial system to play its key role in economic development, this study will help Nigerian banking sector to be ready to absorb any external shock that may pose a threat to the sector's development. Based on our findings, the study will proffer recommendations for policy effectiveness. Very few studies have examined the Performance of Commercial Banks in pre and post reform periods (see Ezirim and Muoghalu, 2004). This study exists to validate their position.

\section{Review of Empirical Literature}

Brownbridge (1996) in a study of the Zambian banking system found that financial policy reforms improved the resilience of the banking industry. The local and foreign banks fare comparatively better than before. Antwi-Asare and Addison (2000) studied the performance of commercial banks in Ghana from 1970 to 1996 to ascertain the effect of financial reforms on banks using primary data obtained from banks and their clients. Their results show mixed conclusions For instance, while the banks revealed specific policy reforms which enhanced their performance to be interest rate liberalization, decontrol of credit allocation and removal of non-performing asset to the Non-performing Asset Recovery Trust; their clients were of the opinion that inflation and high lending rates were the most important factors impeding loan repayment after financial reforms. This shows the fallacy of reforms on the one hand and the role of the macro economy in successful reforms outcomes in the other.

Apparently concerning about profit margins of commercial banks in Malaysia, Guru, Staunton \& Shanmugam (2000) attempt to identify the determinants of successful commercial banks in order to provide practical guides for improved profitability performance of these institutions. The study applied Ordinary Least Squares (OLS) regression technique on a generally unrestricted model where the intercepts are not restricted to be equal over time and cross-sectional units. The study found out that both internal and external determinant of profitability is important for commercial banks. Specifically, an inflationary macroeconomic environment adds with improved interest rate structure to increase the profitability of commercial banks in Malaysia. Overall, commercial banks fared better after reforms. Hardy and Patti (2001) evaluated the effect of banking reforms on the profitability and cost and revenue efficiencies of the banking sector from 1981 to 1997 in the Pakistani economy. They found that the principal effect of financial market reforms seem to have been the increase in both revenues and costs, which suggest that much of benefits of the reforms was passed to the consumers as bank output and those supplying banks with inputs. The reforms did not lead to a rise in overall profitability, which was held down by a combination of rising deposits rates and intensified completion nor did it lead to a strong convergence in all aspect of efficiency. In another related study of the Malawian economy, Mlachila and Chirwa (2002) found that reforms did not improved interest rate spread's behaviour. Interest rate spread continues to widen following liberalization and their panel regression results shows that this could be as a result of high monopoly power, high reserve requirement and high inflation prevailing in the economy. Also following the same trend is Desa (2003). He used linear regression analysis to examine the profitability of commercial banks in Malaysia for a ten year period $(1990$ - 2000) based on six financial variables and two macroeconomic variables. His study suggests that all six variables of the financial sector deliver positively on commercial bank performance during the review period.

Iimi (2004) examined how Pakistani banking sector efficiency can be scale-up through operational specialization and diversification and size expansion between 1998 and 2001. Applying seemingly unrelated regression (SUR) method and stochastic frontier analysis, he found that state owned commercial banks were large enough to obtain cost saving advantages while all other banks could scale-up their operations to obtain good economies. However, he also 
found that scope economies were significant, therefore portfolio diversifications will generally increase bank profits. $\mathrm{Fu}$ and Heffernan (2005) investigated the effect of bank reforms on structure and performance of Chinese commercial banks from 1985 to 2002 using panel data and employing a random effects estimating procedure, they found that gradual reforms affected the structure of Chinese banking market, suggesting that new policies aimed at increasing the market concentration of most banks be pursued.

Lin and Zhang (2006) used panel data of Chinese banks from 1997 to 2004 to examined their performance after ownership reforms and found that the reforms made banks less efficient, less profitable and no performance change ultimately. When Burki and Naizi (2006) carried out similar investigation on Pakistani commercial banks from 1991 to 2000 using DEA, they concluded that the reforms failed to improved bank efficiency at first, but improve after a time lag.

The study of the overall Impact of financial sector reforms and public ownership of financial institutions in Nepal by Adhikary, Pant \& Dhungana (2007), reveals that financial reforms brought significant improvement in Monetary and credit aggregates. Financial reform has certainly had a noticeable impact on the cost of intermediation: real interest rates and gross interest margins. However, there is scope for even more improvements over the next years as competition enhancing measures and administrative costs reduction intervention are adopted. The study combines both primary and secondary data sets to arrive at this conclusion. Shankar and Sanyal (2007) examined the impact of ownership, composition and productivity on profitability spread of commercial banks in India and found that profitable banks are more likely to have a diverse range of output to be operationally efficient and to have a high profitability spread.

Jiang (2008) examined the Chinese commercial banking system using financial ratios and stochastic frontier analysis for the period 1995 to 2005 and found out that the Chinese banking system has stridden down with significant improvement in profitability, capitalization and asset quality. For Aburime (2008), the profitability of commercial banks may not necessarily depend on ownership structure even after the reforms. Using 98 commercial banks and merchant banks in 478 observations over 1989 - 2004 period, and a technique of regression analysis, he showed that composition and ownership structures of these banks have no significant impact on profitability of banks. The study therefore questions the ongoing reforms of the central bank of Nigeria $(\mathrm{CBN})$ into thinking that profitability will come through size composition but rather suggest improved banking environment by the apex bank as a variable.

Mahesh and Bhide (2008) examined the performance of commercial banks in India after reforms for the period 1985 - 2004. They employed stochastic frontier analysis to estimate bank-specific cost, profit and advance efficiencies. Banks were categorized into public banks and private banks. The result shows that while loan advance efficiency has not shown much improvement after reforms, cost and profit efficiencies showed varying trends for different bank groups.
Public sector banks rank first in two of the three efficiency measures, indicating that, as opposed to the general perception, public banks do not lag behind their private bank counterpart in efficiency. They thus concluded that the various impact of the various factors captured in the study is clearly based on performance in a given setting and the rapid changes in the financial sector that are underway will keep influencing the performance of the banking industry.

Heffernan and $\mathrm{Fu}$ (2008b) in an independent study assess how well the different types of Chinese banks have performed between 1999 and 2006 and test for the factor influencing their performance. The variables used include the standard financial ratios, those of which reflect more recent reforms in the banking sector (listing, bank type, the extent of foreign ownership) and macroeconomic variables. Applying GMM estimation technique showed that the reforms did not do much improvement on the sector's performance. The two main indicators of bank reform (listing and foreign equity investment) had no significant influence of performance. Other ways of ensuring performance were then appreciated Heffernan and $\mathrm{Fu}$ (2008a) examined the banking sector trends in total factor productivity (TFP) changes and its components; as well as the relationship between TFP growth and individual banks' financial performance in two Asian countries (China and India ) between 2000 and 2007 using DEA and SFA as estimation technique. Data for their estimation totaled 712 observations from 26 Chinese banks and 63 Indian banks. Evidences showed that technical progress or innovations is the key factor testifying to an outward shift in the best practice frontier.

However, for Ningi and Dutse (2008), consolidation has changed the market structure of the banking system, increased the efficiency and reliability of the banks, created opportunities for financial institutions and market participants and raised their intermediation potentials. Luo (2009) investigated the development of Chinese financial system and reforms of the Chinese commercial banks using 14 commercial banks as case study for the period 1999 to 2008. The study applied both Data Envelopment Analysis (DEA) and Stochastic Frontier Analysis (SFA) to test the effectiveness of Initial Public Offering (IPO) on the efficiency of Chinese banks. Findings reveal a clear changes and significant improvement in the performance of listed banks over the period. This does not mean that all the banks showed the same performance evidence as some banks fall below or just past the threshold bench-mark. Olaosebikan (2009) investigated the efficiency of the Nigerian banking system in the years 1999 to 2005. Bank efficiency was evaluated using DEA and the main determinants were identified using a tobit regression model. The result indicated that efficiency fluctuated during the first period and improved in recent years, a period associated with the increase in minimum capital requirement.

Rajeev and Mahesh (2010) studied the effect of banking sector reforms on non-performing assets (NPAs) on Indian commercial banks and found that reforms were incapable of reducing NPAs of banks in India, suggesting instead the joint 
role of joint liability groups (JLGs) and self help groups (SHGs) in enhancing loan recovery rate in India. Jiang and Yao (2010) applied a one-step SFA model to estimate cost and profit efficiency for 47 commercial banks over the period 1995 - 2008 to evaluate bank performance and investigate the impact of the reform strategies on bank performance. It uses market average input prices when estimating cost and profit efficiency, unlike most studies that used endogenously determined bank specific input prices which contradict the assumptions of cost and profit functions that firms face exogenous input prices in competitive market. The result shows that national banks were more cost efficient, even as profit efficiency was favouring the foreign banks. Overall, bank efficiency has improved over the data period and profit efficiency improved at a faster rate than cost efficiency. The estimated industrial average profit efficiency and cost efficiency are $63 \%$ and $74 \%$ respectively, showing that profit efficiency measure is more appropriate performance measure over cost efficiency when banks have a high level of Nonperforming loans.

Bhatti and Hussian (2010) examined the relationship between market structure and performance of commercial banks in Pakistan in post-reform era (1996 - 2004) using 20 banks as a case study. Applying ordinary least squares (OLS) on the pooled data, the result shows that market concentration will support profitability of the commercial banks after reforms but competition will not improve bank performance in the short run. Kumbirai and Webb (2010) examine the performance of commercial banks in South Africa for the period 2005 - 2009. Financial ratio analysis was employed to measure the profitability, liquidity and credit quality performance of five large South African based commercial banks. The overall result suggests that commercial banks performance increased considerably, but was short-lived due to global financial crisis of 2008. For Ikpefan (2010) banking deregulation in Nigeria from 1986 to 2006 did not make the banks served the public well. In his OLS estimates, management efficiency was negatively related with bank profitability whereas for Adegboyega (2012) the effect was strong and positive. In fact the financial gains from the reforms were more than $2+2=4$ synergistic effects.

Wen (2010) investigated the performance of Chinese commercial banks based on ownership structures for six years (2003 - 2008) using multiple regression analysis. Using ROA and ROE as performance proxy, the result shows that there is no obvious correlation between ownership structure and bank performance in china generally. Huang (2010) collected a sample of 80 Chinese commercial banks for the period 2000 to 2008 to investigate what determine bank performance. The result of the panel data regression showed that at the industry level, the banking system was concentrated and this allows for better performance of the sector.

Abbas and Malik (2010) analyze the market perception about the performance of Pakistani commercial banks due to financial liberalization and deregulation measures taking place in the industry. In their study, 35 commercial banks were analyzed, using what they called distribution free approach for the period 1990 to 2006 . Their result suggested that the banking reforms remain helpful in correcting flaws in the banking sector in Pakistan. In particular, privatization of banks, the deregulation and institutional strengthening measures and switching towards market based monetary and credit management remained helpful in correcting the prevailing flaws of the system.

Bhattacaryya and Pal (2011) examined the technical efficiency of Indian commercial banks for the period 1989 to 2009 using a multiple-output generalized stochastic production frontier after banking reforms. Their result suggests that Indian commercial banks were operating with $64 \%$ efficiency level but that the efficiency declined during most part of the post reform period. Surprisingly, the capital adequacy ratio negatively influences bank efficiency in the period.

The study of the Bangladesh economy by Uddin and Suzuki (2011) shows that after reforms income and cost efficiencies of sampled banks have increased by 37.84 percent and 15.28 percent respectively in 2011 compared to 2008. Also non-performing loans and returns on asset also report improvement in bank performance. Olajide, Asaolu \& Jegede (2011) examined the impact of financial reforms on banks' organizational performance in Nigeria between 1995 and 2004. The study utilized pane data econometrics in a pooled regression where time series and cross-sectional observations were combined for estimation. The outcome showed that financial reforms have a mixed effect on bank profitability level and net interest margin. Bank specific characteristics appear to have a significant effects on bank profitability and efficiency level while industry structure variables appears not to have affected bank profitability and efficiency performance meaningfully.

Lin and Kao (2011) applied Data Envelopment Analysis on 45 commercial banks in Taiwan. Their investigation suggest that focused financial firms (FFFs) fail to achieve gains in the post-reform era. Instead, the performance of commercial banks declines after the financial reforms. There was even little evidence that the financial reforms significantly improve the technical efficiencies of insurance companies and security firms. Oladele, Abosede \& Akeke (2012) examined the performance of Nigerian commercial banks after post consolidation reforms of the banking system using Stochastic Frontier Technique in the years 2006 to 2008. In their study, banks were categorized into healthy and troubled banks to assess their efficiency based on profitability. Profitability was measured by using the transom stochastic profit frontier and independent sample t-test respectively for panel data set of 2006 - 2008 to compare the level of efficiency of the banks. Their result suggests that troubled commercial banks performed better than healthy banks within the period. This allows them to conclude that profitability of commercial banks is not a good measure of performance of commercial banks. The study did not however provide a good measure after all.

Dilshad (2012) assesses the profitability of mergers and acquisition that is ongoing in most banking systems around the 
world. The study covers six (6) European countries of Germany, Spain, Denmark, Italy, Greece and the United Kingdom using what he called 'Event Study Approach'. The result of the study shows that mergers and acquisition in the banking sector tend to be positive for a short period for the acquirer. Thus the performance of the target banks did not improve after merger announcement. Bansal and Gupta (2012) understudy the Indian banking system to examine the performance of the sector after the reforms and concluded that:

"The emerging scenario in the Indian banking system points to the likelihood of the provision of multifarious financial services under one roof. This will present opportunities to banks to explore territories in the field of credit/debit cards, mortgage financing, infrastructure lending, asset securitization, leasing and factory. At the same time, it will throw challenges in the form of increased competition and place strain on the profit margin of Banks"

For Gupta and Aggarwal (2012), the improved performance was a result of influences from general agreement on trade and services. The infusion of Indian banking system by foreign banks after trade liberalization brings with it competition from the new foreign banks to already existing foreign banks and domestic banks and this improves their overall performance scores.

Equally, Nawaz et al (2012) showed that reduced credit risk after reforms can improve commercial banks performance in Nigeria between 2004 and2008. The study employed Correlation and Regression analyses on financial ratios of commercial banks to confirm that credit risk management has a significant impact on the profitability of Nigerian banks. Credit risk is inversely related with banks profitability, thereby caution in credit policy by banks management is a reward. Many authors are of the opinion that financial reform implied by bank consolidation and deregulation affects the competition level of the banking industry more than others. Adams and Agbemade (2012) examined the effect of banking sector reforms implied by financial liberalization and banking sector performance in Ghana for the period 2003 to 2007. The study employed Herfindahl-Hirschman index to test the competitive nature of the banking environment. Evidences suggest that the industry becomes more competitive even when profitability declines. Competition for limited customers, coupled with falling interest rate combined to pile pressure on profitability margins of the industry.

Mogboyin, Asaolu \& Ajilore (2012), examined the responses of flow of credit from the commercial to other sectors in response to reforms and consolidation programmes in the Nigerian banking sector. The study utilizes crosssectional data from 89 pre-consolidation banks and 25 postconsolidation banks to ascertain the credit performance based on pooled panel data regression. Their findings show that banking reforms induced changes in bank structure in terms of size and capitalization and positively influenced bank lending performance. This suggest that banking respond to business cycles, expanding credit during booms and contracting it during recession implying that the new consolidation policies in Nigerian banking system has been a major breakthrough in the history of banking regulation in Nigeria. In a similar study, Allen, Carletti, Cull, Qian, Senbet \& Valenzuela (2012) investigated the extent in which Kenyan economy has benefited inclosing the financial resources gap over the country's significant strides in financial reforms implied by financial inclusion and development in recent years using multiple regression technique. Their result indicated a positive and significant impact on Equity Bank, a leading private commercial bank on financial access, especially for under-served (under-privileged) households and generating sustainable profits in the process. The study therefore modeled Equity Bank as a potential solution to the financial access problem that has hindered the development of inclusive financial sectors in many other African countries to which other banks can follow.

Keovongvichith (2012) examined the performance of Laotian commercial banks following the reforms of their banking sector over five years $(2005-2010)$. In his study, certain key indicators of commercial banks were investigated including capital adequacy, asset quality, management efficiency, earning and profitability and liquidity, using the CAMEL test approach. The result show that reforms did not improved the performance of banks in the country or may not have been enough to trigger noticeable performance.

Ani, Ugwunta, Ezeudu \& Ugwuanyi (2012) examined the effect of bank consolidation on cost savings for consolidated banks in Nigeria for ten year-period (2000 - 2009). The study proxied cost income ratio (CIR) as a measure of cost savings for six banks in Nigeria. Their findings revealed that the sampled banks recorded decreases and increases in the operating variable at various intervals of the pre and post consolidation period. The study then argued that banking reforms implied by bank consolidation has not achieved cost savings for commercial banks in Nigeria.

Simpasa (2013) examined how competitive the Zambian banking system will be for the period 1998 to 2011 using Panzar-Rose (PR) methodology and the more dynamic Lerner Index. The result of the study indicates that over the sampled period, Zambian commercial banking system exhibited elements of monopolistic competitive behaviour. Competitiveness was not as low as previously understood. Gargouri (2013), did a similar study of the Tunisian banking system but using what he called 'Intermediation Approach'. Intermediation Approach to performance evaluation see the liability of commercial banks as an input other than an output. The result shows that size of banks influence performance of banks in terms of profit.

In their study Ofoegbu and Iyewumi (2013) employed a multiple ordinary least square regression (OLS) on some variables in the banking system to explain the effect of deregulation and consolidation on the level of competition in the Nigerian banking industry. The study proxied variables such as interest rate spread, among others as a measure of competition. The result shows that both deregulation and 
consolidation lowers the gap between interest rate spread, thus enforcing a competitive banking environment. However, the magnitude of the reform effect on competition is yet to be substantial as the poor probability value of less than 0.05 suggests that its effect is still insignificant. In a study of the real determinants of profitability of commercial banks in Nigeria within the period of the reforms, taking cognizance of the recent global financial crisis, Aremu, Ekpo \& Mustapha (2013) found that cost efficiency measure did not significantly determine bank profitability in Nigeria. The study applied econometric analysis of cointegration and error correction technique on data obtained from First Bank of Nigeria as case study between 1980 and 2010.

Kamau and Were (2013) analyzed the driving factors behind the impressive banking sector performance in Kenya for 13 years $(1997$ - 2011) using DEA and found that the supporting base for such drive was the systems' market structure. In such study undertaken by Ongore and Kusa (2013) in Kenya, macroeconomic factors failed to improve the performance of commercial banks. Commercial banks were mainly driven by board of management decisions. Kiruri (2013) investigated the effect of ownership structure on bank profitability in Kenya using primary data structured to meet that objective. The result of his findings indicated that ownership concentration and state ownership has a negative and significant effect on bank profitability within the reform period.

Garza-Garia (2011) took steps to analyze the determinants of commercial bank performance after consolidation. In the study, two market power hypotheses, Structure-ConductPerformance (SCP) and Relative-Market-Power (RMP) alongside two variants of the Efficient-Structures (ES) hypothesis were tested in order to find out whether bank performance has been driven by Market Structural effects or by greater efficiency between 2001 and 2009.using two step method: first, the two efficiency estimators namely $\mathrm{X}$ efficiency (ESX) and Scale-efficiency (ESS) were computed by applying the non parametric data envelopment analysis (DEA) method and second, a dynamic panel system GMM regression was applied. The outcome revealed that the banking system in Mexico has experienced average inefficiencies of around $12 \%$ for both measures of efficiency estimated for the study period. However, the findings also show that profit persisted, but they adjusted to their natural level slowly,

\section{Methodology}

In other to examine the short and long term effect of banking sector reforms on the performance of Commercial banks in Nigeria, Co-integration analysis will be used. Economic theory often suggests that certain subsets of variables are linked by a long-run equilibrium relationship. Although the variables under consideration may drift away from equilibrium for a while, economic forces or government actions may be expected to restore equilibrium. Cointegration analysis is expected to highlight both the short and long term relationship between banking sector reforms and commercial bank performance.

At least there is a verifiable relationship between bank performance and reform. Brissimis et al (2008) have specified the following empirical model to study the relationship between the performance, reform, competition and risk-taking in banking.

$$
\mathrm{P}_{\mathrm{it}}=\alpha_{0}+\alpha_{1} \mathrm{ref}_{\mathrm{t}}+\alpha_{2} \theta \mathrm{i}+\alpha_{3} \mathrm{x}_{\mathrm{it}}+\alpha_{4} \mathrm{~m}_{\mathrm{t}}+\mu_{\mathrm{it}}
$$

where the performance $\mathrm{P}$ of bank $\mathrm{i}$ at time $\mathrm{t}$ is written as a function of a time-dependent banking-sector reform variable, reft, an index of banking industry market power, $\theta$; a vector of bank-level variables representing credit, liquidity and capital risk, $\mathrm{x}$; variables that capture the macroeconomic conditions common to all banks, $\mathrm{m}$; and the error term, $\mu$.

Therefore, following Brissimis et al (2008), we specify our modified implicit model thus;

$$
\Pi_{\mathrm{t}}=\mathrm{F}\left(\mathrm{NPL}_{\mathrm{t}}, \mathrm{PR}_{\mathrm{t}}, \mathrm{CR}_{\mathrm{t}}, \pi_{\mathrm{t}}^{\mathrm{e}}, \mathrm{RGDP}_{\mathrm{t}}\right)
$$

Where, $\Pi_{t}=$ The performance of bank at time t proxied by NIM; $N P L_{t}=$ Non-performing Loan of bank at time t proxied by investment of Commercial Banks; $P R_{t}=$ Lending rate of Interest of bank at time t; $C R_{t}=$ Credit Allocation to the Private Sector by bank at time $\mathrm{t} ; R G D P_{t}=$ Growth rate of gross domestic product at time $\mathrm{t} ; \pi^{e}{ }_{t}=$ Inflation rate in the economy; $\mu_{\mathrm{t}}=$ error term.

To examine the performance of commercial banks before and after the Reforms, we adopt both descriptive and econometric approach. Based on the earlier outcome, we used Chow test analysis to determine which period of the reforms was more beneficial to the Nigerian economy and the banking sector. Nigeria followed a regulated reformed period between (1970-1985) and deregulated reformed period thereafter (1986-2012) and beyond.

The chow test is specified as;

$$
\mathrm{F}=\frac{\left(\sum \mathrm{e}_{3}^{2}-\mathrm{RSS}_{\mathrm{u}}\right) / \mathrm{K}}{\left(\mathrm{RSS}_{\mathrm{u}}\right) /\left(\mathrm{N}_{1}+\mathrm{N}_{2}-2 \mathrm{~K}\right)}
$$

Where, $\mathrm{N}_{1}$ is sample data when Nigeria was operating regulated financial system (1970-1985), $\mathrm{N}_{2}$ is sample data when the Nigerian banking system was deregulated (19862012), $\sum \mathrm{e}_{3}{ }^{2}$ is Sum of Squared Residual for the pooled data (1970-2012), $\mathrm{RSS}_{\mathrm{u}}$ is Sum of Squared Residual for $\mathrm{N}_{1}$ period plus Sum of Squared Residual for $\mathrm{N}_{2}$ period $\left(\sum \mathrm{e}_{1}{ }^{2}+\sum \mathrm{e}_{2}{ }^{2}\right)$, and $\mathrm{K}$ is Degree of freedom.

To identify the source of the instability in the performance of commercial banks in the period, we test for differences in intercept and slope coefficients. Following Ukoha and Nwabuko (2006), we specify our test formulas as;

Test for differences in intercept

$$
\mathrm{F}=\frac{\left(\sum \mathrm{e}_{3}^{2}-\sum \mathrm{e}_{4}^{2}\right) /\left(\mathrm{K}_{3}-\mathrm{K}_{4}\right)}{\left(\sum \mathrm{e}_{4}^{2} / \mathrm{K}_{4}\right)}
$$

Where, $\sum \mathrm{e}_{3}{ }^{2}$ is Sum of Squared Residual for the pooled 
data (1970-2012) with $\mathrm{K}_{3}$ degree of freedom; $\sum \mathrm{e}_{4}{ }^{2}$ is Sum of Squared Residual for the pooled data (1970-2012) with a dummy variable $D_{t}$ and $K_{4}$ degree of freedom.

Test for homogeneity of slopes

$$
\mathrm{F}=\frac{\left(\sum \mathrm{e}_{4}^{2}-\sum \mathrm{e}_{1}^{2}-\sum \mathrm{e}_{2}^{2}\right) /\left(\mathrm{K}_{4}-\mathrm{K}_{1}-\mathrm{K}_{2}\right)}{\left(\sum \mathrm{e}_{1}^{2}+\sum \mathrm{e}_{2}^{2}\right) /\left(\mathrm{K}_{1}+\mathrm{K}_{2}\right)}
$$

Where, $\sum \mathrm{e}_{1}^{2}$ is Sum of Squared Residual for regulated reform period with $\mathrm{K}_{1}$ degree of freedom; $\sum \mathrm{e}_{2}^{2}$ is Sum of Squared Residual for deregulated reform period with $\mathrm{K}_{2}$ degree of freedom. Generally, it follows that if the calculated $\mathrm{F}$ ratio is greater than the table $\mathrm{F}$ ratio, both the intercept and slope will be significantly different within the periods.

\section{Results and Discussion}

The time series properties of the variables were explored to determine the order of integration of each variable in the model. The table 4.0 shows the result of unit root test of the Variables using augmented Dickey Fuller test.

Table 4.0. Unit Root Test Results

\begin{tabular}{llllll}
\hline Variables & ADF at level & ADF at $1^{\text {st }}$ diff. & Mckinnon Critical Value (5\%) & P-value & Order of Integration \\
\hline $\log$ NIM & -1.498439 & $-11.35708^{*}$ & -2.935001 & 0.0000 & $1(1)$ \\
$\operatorname{logNPLs}$ & -0.461446 & $-4.498031^{*}$ & -2.935001 & 0.0008 & $1(1)$ \\
$\log$ PR & -1.293508 & $-11.02415^{*}$ & -2.935001 & 0.0000 & $1(1)$ \\
$\log$ CR & -2.215235 & $-6.034814^{*}$ & -2.935001 & 0.0002 & $1(1)$ \\
$\log$ INFL & $-4.506263^{*}$ & & -2.933158 & 0.0008 & $1(0)$ \\
$\operatorname{logRGDP}$ & -0.350100 & $-5.658260^{*}$ & -2.935001 & 0.0000 & $1(1)$ \\
\hline
\end{tabular}

Note: * indicates significance at $5 \%$

Source: Researcher

The results of Table 4.0 show that except for log of inflation, all other variables were non-stationary at levels since their ADF values are less than the critical values at $5 \%$,( for which the study adopt). The null hypothesis of a unit root was accepted for all the other variables (except inflation) at level. We rather rejected the null hypothesis at 1 st difference and accept the alternative hypothesis that the variables are all stationary. Thus, we conclude that the variables under investigation are integrated of order one. (i.e. I(1)) except inflation which is of the order 1(0). Since the variables are integrated, we therefore, examine the cointegrating relationship of the variables using Johansen cointegration procedure. The result is presented in Tables 4.1.

Table 4.1. Johansen Cointegration Test Result between $\log N I M, \log N P L s, \log P R, \log C R, \log I N F L$ and $\log R G D P$

\begin{tabular}{|c|c|c|c|c|c|}
\hline Hyp. No of CE(s) & Eigenvalue & Trace Statistics & 0.05 Critical Value & Max-Eigen Statistic & 0.005 Critical Value \\
\hline None * & 0.683743 & $124.8769 *$ & 95.75366 & $47.19917^{*}$ & 40.07757 \\
\hline At most $1^{*}$ & 0.576210 & $77.67770 *$ & 69.81889 & $35.19924 *$ & 33.87687 \\
\hline At most 2 & 0.413643 & 42.47846 & 47.85613 & 21.88688 & 27.58434 \\
\hline At most 3 & 0.246740 & 20.59157 & 29.79707 & 11.61715 & 21.13162 \\
\hline At most 4 & 0.195842 & 8.974426 & 15.49471 & 8.936338 & 14.26460 \\
\hline
\end{tabular}

Note: * denote rejection of the null hypothesis at 0.05 level Both trace and max-eigen values indicate two cointegrating equations at 0.05 level of significance Source: Researcher

From Table 4.1, both the trace test and the Max-Eigen test statistics indicates the presence of at least two co-integrating equations at $5 \%$ level of significance which implies that commercial bank performance and the independent variables are co-integrated. It further shows that there is a long-run relationship between commercial bank performance and banking sector variables which are influenced by the various reforms taking place in the sector in recent times which should be investigated. Thus we reject the hypothesis of no co-integration and proceed with the investigation of the cointegrating relationship. The idea is to start with a model with too many variables (usually the lag values of the variables in the co-integrating equation are preferred), technically called over-parammetised model and then reducing it to a more preferred model with highly significant parameters, also called parsimonious or preferred model in technical terms. The result of the over-parametised model is presented in Table 4.2.

From Table 4.2, it was revealed that Non Performing Loans (proxied by investment of Commercial Banks), interest rate, credit supply to the private Economy, real gross domestic product and inflation are all immediate multipliers that affect the performance of Commercial Banks in Nigeria at various levels of significance. Of much interest were the positive effect of Non Performing Loans and the price of credit in determining future levels of profit by commercial banks in Nigeria. The result shows that specifically, a 1 percent increase on average in Non Performing Loans and 
the price of credit will lead to about 4.8 percent increase in current profit of banks respectively. Commercial banks may not make good returns on credit supplied to the private sector as time passes. As time passes, the credit channels may produce significant effects capable of improving the loan channels also to the tune of one to one percentage point on average profit. The effect of real GDP will be mixed and will be positive significantly, after some time lag. The result also shows that Commercial Banks may suffer on the continued falling prizes in the economy in their profit motive. Falling domestic prices (inflation) of say 1 percent is shown to reduce the performance of Commercial Banks in Nigeria by about 0.35 percent in three years.

Table 4.2. Over-paramaterized Error Correction Result for Model (2a) Dependent variable: $\Delta l o g N I M$

\begin{tabular}{|c|c|c|c|c|}
\hline & Coefficient & Std. Error & t-ratio & p-value \\
\hline Const & $-0.6788 * * *$ & 0.1684 & -4.0315 & 0.00060 \\
\hline$\Delta \log N P L s$ & 0.3979 & 0.3442 & 1.1560 & 0.26068 \\
\hline$\Delta \operatorname{logNPLs} 1$ & 0.6766 & 0.4548 & 1.4877 & 0.15170 \\
\hline$\Delta \operatorname{logNPLs\_ 2}$ & $0.7501 * *$ & 0.3460 & 2.1679 & 0.04181 \\
\hline$\Delta \log P R$ & $1.7942 * * *$ & 0.2274 & 7.8904 & 0.00001 \\
\hline$\triangle \log P R \quad 1$ & 0.3011 & 0.3982 & 0.7562 & 0.45792 \\
\hline$\Delta \log P R \_2$ & $0.7516 * *$ & 0.3369 & 2.2314 & 0.03669 \\
\hline$\Delta \log C S P S \_1$ & $-0.7184 * *$ & 0.3220 & -2.2310 & 0.03671 \\
\hline$\Delta \log C S P S \_2$ & $0.9627 * * *$ & 0.2423 & 3.9734 & 0.00069 \\
\hline $\log I N F L$ & $-0.09023^{*}$ & 0.0508 & -1.7761 & 0.09021 \\
\hline $\log I N F L \_1$ & $-0.1277^{*}$ & 0.0625 & -2.0436 & 0.05374 \\
\hline $\log I N F L \_2$ & $-0.1257^{*}$ & 0.0654 & -1.9213 & 0.06838 \\
\hline$\Delta \log G D \bar{P}$ & 0.1992 & 0.3593 & 0.5545 & 0.58510 \\
\hline$\Delta \log G D P \_1$ & -0.6495 & 0.4706 & -1.3802 & 0.18203 \\
\hline ECM_1 & $-0.4723 * *$ & 0.1828 & -2.5836 & 0.01733 \\
\hline Mean dependent var & 0.004558 & & S.D. dependent var & 0.614687 \\
\hline Sum squared resid & 1.082865 & & S.E. of regression & 0.227079 \\
\hline R-squared & 0.926515 & & Adjusted R-squared & 0.863527 \\
\hline $\mathrm{F}(18,21)$ & 120.9624 & & P-value(F) & $3.33 \mathrm{e}-17$ \\
\hline Log-likelihood & 15.42784 & & Akaike criterion & 7.144328 \\
\hline Schwarz criterion & 39.23304 & & Hannan-Quinn & 18.74659 \\
\hline Rho & 0.040814 & & Durbin-Watson & 1.797469 \\
\hline
\end{tabular}

Note: $*, * *, * *$ denote significance at 10,5 , and $1 \%$ respectively

Source: Researcher

Table 4.3. Parsimonious Error Correction Result Dependent variable: $\triangle \log N I M$

\begin{tabular}{|c|c|c|c|c|}
\hline & Coefficient & Std. Error & t-ratio & p-value \\
\hline Const & $-0.5255^{* * *}$ & 0.1288 & -4.0782 & 0.00036 \\
\hline$\Delta \log N P L s$ & $0.5463 * *$ & 0.2292 & 2.3837 & 0.02443 \\
\hline$\Delta \operatorname{logNPLs\_ 2}$ & $0.6483 * *$ & 0.2356 & 2.7517 & 0.01046 \\
\hline$\Delta \log P R$ & $1.5732 * * *$ & 0.1648 & 9.5435 & 0.00001 \\
\hline$\Delta \log P R \_2$ & $0.6039 * * *$ & 0.2172 & 2.7801 & 0.00978 \\
\hline$\Delta \log C R^{*}$ & $-0.3524 * *$ & 0.1471 & -2.3959 & 0.02378 \\
\hline$\Delta \log C R * 1$ & $-0.6759 * *$ & 0.2799 & -2.4145 & 0.02280 \\
\hline$\Delta \log C R^{*} 22$ & $1.1068 * * *$ & 0.2421 & 4.5722 & 0.00010 \\
\hline $\log I N F L \_2$ & $-0.0739 * *$ & 0.0296 & -2.4981 & 0.01887 \\
\hline$\Delta \operatorname{logRGDP} \_1$ & $-0.7803 * *$ & 0.3312 & -2.3560 & 0.02599 \\
\hline$\Delta \operatorname{logRGDP} 2$ & $1.6137 * * *$ & 0.2808 & 5.7458 & 0.00001 \\
\hline ECM_1 & $-0.5528 * * *$ & 0.0838 & -6.5996 & 0.00001 \\
\hline Mean dependent var & 0.004558 & & S.D. dependent var & 0.614687 \\
\hline Sum squared resid & 1.276660 & & S.E. of regression & 0.217448 \\
\hline R-squared & 0.913363 & & Adjusted R-squared & 0.874858 \\
\hline $\mathrm{F}(12,27)$ & 46.27433 & & P-value(F) & $7.91 \mathrm{e}-15$ \\
\hline Log-likelihood & 12.13511 & & Akaike criterion & 1.729782 \\
\hline Schwarz criterion & 23.68521 & & Hannan-Quinn & 9.668173 \\
\hline Rho & 0.033618 & & Durbin-Watson & 1.812677 \\
\hline
\end{tabular}

Note: $* *, * * *$ represent significance at 5 and $1 \%$ respectively

Source: Researcher 
The result of the preferred model is reported in Table 4.3. The result shows that non performing loans in current and lagged period two is positively significant. This means that a lot of revenue accrues to commercial banks in Nigeria from loans recovery. Taken by itself a 1 percent increase in investment by commercial banks may lead to a revenue rise of not less than 1.2 percent in the short run. This justify why the reforms were necessary. Available statistics shows that the non performing loans rating of banks decline from 18.1 in 2005 to 9.3 in 2006 and 7.2 in 2008. The NPLs for commercial banks in Nigeria were 3.5 and 3.2 respectively for 2012 and 2013.This realization confirms the position of Kumbirai and Webb (2010) that studied the effect of banking sector reforms on the performance of commercial banks in South Africa and found that reforms were capable of increasing the performance of commercial banks considerably. Interest rate was positive and significant in the current and lagged period. It however, shows that any further rise in interest rate may reduce investment and possibly the profit level of commercial banks may fall. Thus, in response to this fact, interest rate must fall, but still positive to induce savings in commercial banks. This is consistent with economic theory. Commercial banks will make more profit if they extend more credit to the private sector. This is shown by positive significant credit supply levels to the economy in lagged period two. However, if prudent management of the facility by both the lender and the recipient is not in place, losses may occur, as shown by the negative significant level of current credit supplies. Inflation was negative and significant over the period. This implies that the macroeconomic environment was user friendly for commercial bank performance. Commercial banks may have gained a large chunk of their profit through this favourable cost of doing business in Nigeria over the period. The positive significant real GDP in lag two period shows that commercial banks were profitable by servicing the production activities of the economy. At least every 1 percent of financial services to the economy earned them about 1.6 percent income from their investment. Thus, commercial banks in Nigeria capitalize on the favourable macroeconomic environment to increase their margin. For instance, the profit margin of Nigeria's commercial banks grows from single digit of 9.17 in 1996 to 21.86 in 2001 and 24.62 in 2004. Overall, right from 1997 onward, commercial banks have flourished on double digits profit margin until 2011 see figure 1.1). Overall, the model shows that any disequilibrium in long run total profit accruing to commercial banks in Nigeria will be adjusted within two years. Our model also shows a minimum Akaike Information Criterion (AIC) and Schwarz Bayesian Criterion (SBC) of 1.73 and 23.69 values respectively. The problem associated with serial correlation is also ruled out given our DW statistic of 1.8. The model also explains more than 87 percent of variation in profit levels of the commercial banks in the period under review. In general, our findings shows that the performance of Commercial banks may improves significantly within the earlier periods of reforms, and may be maintained if well managed in the years following reforms.

Next, we investigate the performance periods of the reforms. Under the null hypothesis that there is no significant difference between the coefficients obtained in the two different periods, we conduct our Chow test. The result of the chow test is presented in Table 4.4.

Table 4.4. Presentation of Chow test Result

\begin{tabular}{lllll}
\hline Variables & Total & DF & Formula & Formula DF \\
\hline SSR Pooled data & 6.4346 & 37 & & $\mathrm{~N} 1+\mathrm{N} 2-\mathrm{K}$ \\
SSR (N1) & 0.2497 & 10 & & $\mathrm{~N} 1-\mathrm{K}$ \\
SSR (N2) & 2.5208 & 21 & $\mathrm{~N} 2-\mathrm{K}$ \\
& & & + & $\mathrm{N} 1+\mathrm{N} 2$ \\
$\mathrm{Q}^{*}$ & 2.7705 & 31 & $\mathrm{SSR}(\mathrm{N} 2)$ & - \\
& & & $\mathrm{SSR}(\mathrm{pooled})$ & $\mathrm{K}$ \\
$\mathrm{Q}^{* *}$ & 3.6641 & 6 & - & $\mathrm{SSR}(\mathrm{N} 1+\mathrm{N} 2)$ \\
$\mathrm{F}_{0.05}^{*}$ & & $\mathrm{Q}{ }^{* *} / \mathrm{K} /$ & \\
$\mathrm{F}_{0.05} 6,31$ & & $\mathrm{Q} /(\mathrm{N} 1+\mathrm{N} 2-2 \mathrm{~K})$ & \\
2.34 & 6.8311 & & & \\
\hline
\end{tabular}

Source: Researcher

From Table 4.4, the calculated $F$ ratio is 6.83 . When compared with the Theoretical $\mathrm{F}$ ratio at 5 percent level of significance, the alternative hypothesis could not be rejected. Stated specifically, the theoretical F ratio of 2.34 allows us to reject the null hypothesis. This means that the performance of commercial banks in Nigeria differed significantly within regulated and deregulated period of bank reforms. The performance of commercial banks in Nigeria changes over times due to the various reforms taking place in the sector in recent times. Specifically, the level of profit continues to improve above single digit in the reform period. For instance, the profit margin of Nigeria's commercial banks grows from single digit of 9.17 in 1996 to 21.86 in 2001 and 24.62 in 2004 and only falling to 20.96 in 2011 . A mean profit of 1.54 was recorded in the regulated period as against 2.40 recorded in the deregulated period (see Appendix 2, Tables C2 and C3). Overall, right from 1997 onward, commercial banks have flourished on double digits profit margin until 2011 ( see 
figure 1.1). Shah (2007) and Odeleye (2014), in their separate study, had found such positive outlook on the banking system

after reforms.

Table 4.5. Regression results for test of equality between intercepts and slopes Dependent variable: log NIM

\begin{tabular}{lllll}
\hline Explanatory Variables & Pre-Reform Period & Post-Reform Period & Polled Regression & Dummy Regression \\
\hline \multirow{2}{*}{$\operatorname{logNPLs}$} & 0.1157 & $-0.2284^{* *}$ & -0.1561 & -0.2528 \\
& $(1.6692)$ & $(-2.4201)$ & $(-0.4224)$ & $(-0.7196)$ \\
$\log \mathrm{PR}$ & $1.8812^{* * *}$ & $1.6419^{* * *}$ & $0.5679^{* *}$ & $(.1177$ \\
& $(6.6110)$ & $(4.1395)$ & $(2.1469)$ & $(3.2628)^{* * *}$ \\
$\log \mathrm{CR}$ & 0.3335 & $1.0967^{* *}$ & -0.4153 & -0.3333 \\
& $(1.1835)$ & $(2.0875)$ & $(-1.0780)$ & $(-0.9120)$ \\
$\log \mathrm{NNFL}$ & $-1.2704^{* * *}$ & $-0.9842^{* *}$ & $-0.2495^{* *}$ & $-0.2089^{* *}$ \\
& $(-3.3711)$ & $(-2.4185)$ & $(-2.8178)$ & $(-2.4470)$ \\
$\operatorname{logRGDP}$ & $1.1046^{* *}$ & $1.1646^{* *}$ & 0.3119 & $(1.27483$ \\
& $(2.7749)$ & $(2.8847)$ & $(0.8487)$ & $-0.7440^{* *}$ \\
$\mathrm{D}_{\mathrm{t}}$ & & & & $(-2.3451)$ \\
& & & & -2.2611 \\
$\mathrm{C}$ & -5.3384 & -10.0589 & -0.1190 & $(-1.2398)$ \\
$\mathrm{R}^{2}$ & $(-2.5849)$ & $(-3.6833)$ & $(-0.0712)$ & 0.7504 \\
Adjusted $\mathrm{R}^{2}$ & 0.8927 & 0.8000 & 0.7122 & 0.7088 \\
$\mathrm{~F}$ & 0.8391 & 0.7524 & 0.6733 & 18.0350 \\
Prob(F) & 16.6464 & 16.8016 & 18.3147 & 0.000000 \\
$\sum \mathrm{e}^{2}$ & 0.000145 & 0.000001 & 0.000000 & 5.5819 \\
$\mathrm{DW}$ & 0.2497 & 2.5208 & 6.4346 & 1.8520 \\
\hline
\end{tabular}

Note: $* *, * * *$ denote significance at $5 \%$ and $1 \%$ respectively Figures in brackets are t-ratios

Source: Researcher

Having identified the existence of structural instability in banking reforms period in Nigeria we desire to investigate the source of the change. This is done by introducing a dummy variable (in an additive manner) to differentiate between the intercepts of the two periods respectively in a single model and then conducting the F-test. The result of the analysis is presented in table 4.5. From Table 4.5 , it can be seen that the dummy variable that represent the differential intercept $D_{t}$ is statistically significant at 5\% level of significance, thus sending positive signal that there may be difference between the intercept of the regressions in the two reform periods. When the F-test for differences in intercepts was conducted, the result is presented in Table 4.6.

Table 4.6. Result of test for differences in intercept

\begin{tabular}{llll}
\hline & Error sum of squares & Degree of freedom & Cal.F-statistic \\
\hline Polled Regression & 6.4346 & 37 & 5.4977 \\
Dummy Regression & 5.5819 & 36 & \\
\hline
\end{tabular}

Source: Researcher

The calculated $\mathrm{F}$ ratio of 5.50 was compared with the theoretical $F_{1,36}$ of 4.08 . The result shows that the null hypothesis of no difference in the performance of commercial banks in the two reformed periods should be rejected. The productivity of commercial banks within the two periods is but dissimilar in the period under review. However, when the slope component of the result was examined, it was found that the calculated $\mathrm{F}$ ratio of 6.3 greater than theoretical $F_{5,31}$ of 2.45 also made the differential slope coefficient statistically significant (Table 4.7)

Table 4.7. Result of test for homogeneity of slopes

\begin{tabular}{llll}
\hline Reform periods & $\begin{array}{l}\text { Error sum of } \\
\text { squares }\end{array}$ & $\begin{array}{l}\text { Degree of } \\
\text { freedom }\end{array}$ & $\begin{array}{l}\text { Cal. F- } \\
\text { statistic }\end{array}$ \\
\hline Pre-reform & 0.2497 & 10 & \\
Post-reform & 2.5208 & 21 & \\
$\begin{array}{l}\text { Dummy } \\
\text { Regression }\end{array}$ & 5.5819 & 36 & 6.2897 \\
\hline
\end{tabular}

Source: Researcher
Thus, we cannot accept the null hypothesis that the two banking period have the same slope. We rather conclude that the two banking period differs in slope. The structural instability identified by Chow test came from both the intercept and the slope term. Banking reforms therefore grows the performance and productivity of commercial banking activities in Nigeria in the period under review. The reforms, working under the cover of monetary aggregates improves the performance of other macroeconomic indicators including inflation and interest rate in the country so much so that the banking system is not worse off.

\section{Conclusion}

The study investigated the effects Banking Sector Reforms on the Performance of Commercial Banks in Nigeria between 1970 and 2012. The findings proved that in terms of profit performance for banks, Reforms of the banking sector was able to generate good benefits to the 
system. Overall, banking sector reforms implied by deregulation is advocated for Nigeria given that positive structural differences exist to support this assertion. Specifically, the level of profit continues to improve for commercial banks over and above the regulated period in the deregulated period. A mean profit of 0.86 was recorded in deregulated period over regulated period. The study found out that reform in the banking sector increases the efficiency (profitability) of commercial banks. This is seen in large interest-rate spreads between deposit and lending rates particularly from 1997 to 2011, where interest rate spread takes double digit. This is an indication that competition in the banking sector is still not strong enough. A more competitive banking sector would limit the ability of banks to increase interest-rate spreads. High interest-rate spreads are problematic because they penalize depositors and discourage investment. The increase in such spreads following reforms therefore suggests that the sector is still in need of policies to encourage more competition. This forms the focus of our recommendation. A review of banking sector costs is necessary, in order to identify them and lead to policies to reduce them.

\section{References}

[1] Abbas, K. And Malik, M. H. (2010). Impact of Financial Liberalisation and Deregulation on Banking Sector in Pakistan, Pakistan Institute Of Development Economics (PIDE) Working Paper No 64, Islamabad.

[2] Aburime, U. T. (2008). Impact of Ownership Structure on Bank Profitability in Nigeria, Available online at www.feb.uva.nl/rof/58, 16/05/2013.

[3] Adams, S. and Agbemade, J. (2012).Financial Liberalization and Banking Sector Performance in Ghana, African Journal of Business Management, 6(47):11598-11608.

[4] Adegboyega, O. I. (2012). Mergers and Acquisitions and Banks Performance in Nigeria, Jorind, 10(2): 338-347.

[5] Adhikary, D. K., Pant, R. \& Dhungana, B. R. (2007). Study on Financial Sector Reforms in Nepal (Overall Impact and Public Ownership of Financial Institutions), Paper prepared for South Asian Network of Economic Institutes (SANEI), New Baneswore, 18-21 June.

[6] Allen, F., Carletti, E., Cull, R., Qian, J., Senbet,L. and Valenzuela, P. (2012). Resolving the African Financial Development Gap: Cross-Country Comparisons and a WithinCountry Study of Kenya, Forthcoming in NBER Volume on African Economic Successes, Available online at cadmus.eui.eu, 05/05/2013.

[7] Ani, W. U., Ugwunta, D. O., Ezeudu, I. J. and Ugwuanyi, G. O. (2012). An Empirical Assessment of the Determinants of Bank Profitability in Nigeria: Bank Characteristics Panel Evidence, Journal of Accounting and Taxation , 4(3): 38-43.

[8] Antwi-Asare, T. O. and Addison, E. K. Y. (2000). Financial Sector Reforms and Bank Performance in Ghana, Overseas Development Institute, University of Ghana : 81-86.
[9] Aremu, M. A., Ekpo, I. C. And Mustapha, A. M. (2013) Determinants of Banks' Profitability in a Developing Economy: Evidence from Nigerian Banking Industry, Interdisciplinary Journal Of Contemporary Research In Business, 4(9): 155-181.

[10] Asogwa,R.(2005)."Assessing the Benefits and Costs of Financial Sector Reform in Nigeria:An Event Study Analysis", Selected Papers for $46^{\text {th }}$ Annual Conference, Nigerian Economic Society, 23-25 August

[11] Balogun, E. D. (2007). Banking Sector Reforms and the Nigerian Economy: Performance, Pitfalls, and Future Policy Options, Munich Personal RePEc Archive (MPRA) Paper No. 3804, Available online at http://mpra.ub.unimuenchen.de/3804/, 22/03/2014.

[12] Bansal, S. And Gupta S. K.(2012). A Study Of Banking Sector In India After Reforms, International Journal Of Research In It \& Management (Ijrim), 2 (7): 40-48.

[13] Bhattacharyya, A. and Pal, S.(2011). Financial Reforms and Technical E_ciency in Indian Commercial Banking: A Generalized Stochastic Frontier Analysis, Available online at http://www.shsu.edu/ eco_www/, 17-06-2014.

[14] Bhatti, G. A. and Hussain, H.(2010). Evidence on Structure Conduct Performance Hypothesis in Pakistani Commercial Banks, International Journal of Business and Management, 5(9): 174-187.

[15] Brissimis, S. N., Delis, M.D., and Papanikolaou, N.I. (2008). Exploring the Nexus between Banking Sector Reforms and Performance :Evidence from newly acceded EU Countries, Bank of Greece working paper no 73, available online @ www.bankofgreece.gr, visited 21/03/2014simi

[16] Brownbridge, M. (1996). Financial Policies and the Banking System in Zambia, Available online at http://www.ids.ac.ukfiles/wp32, 09-05-2013.

[17] Burki A A and Nazi, G. S. K. (2006). Impact of Financial Reforms on Efficiency of State-owned, Private and Foreign Banks in Pakistan, CMER working paper no 06-49, Lahore, Lahore University of Management Sciences.

[18] Central Bank of Nigeria (2005a) A Case Study of Distressed Banks in Nigeria.

[19] Central Bank of Nigeria (2005b) Banking Supervision Annual Reports: 10.

[20] Desa, K. A. (2003). An Analysis of the Determinant of Commercial Banks Profitability in Malaysia, Unpublished Ph. D Thesis, Perpustakaan Sultanah Bahiyah Universiti Utara, Malaysia, Available online at etd.uum.edu.my/1018/, 26-052013

[21] Dilshad, M. N. (2013). Profitability Analysis of Mergers and Acquisitions: An Event Study Approach, Journal of Macrothink Institute Business and Economic Research, 3 (1): 89-125.

[22] Ekong, U. M and Ikot, A. S. (2012). Nigerian Banks Potentials and NEEDS: A Nexus for Pro-poor Growth in Nigeria, unpublished seminar paper of the Faculty of Education, University of Uyo.

[23] Ezirim, C.B.and Muoghalu, M. D. (2004). Financial Reforms and Commercial Banks Operations in Nigeria: AComparison of Two Decades, Union Digest, 8(2): 24-50. 
[24] Fu, X. and Heffernan, S.(2005). China: The Effects of Bank Reform on Structure and Performance, Paper presented at the Annual Wolpertinger Conference (European Association of University Teachers in Banking and Finance), Cass Business School, City University-London, 31 August - 3 September.

[25] Gargouri, I. (2013). Efficiency of Tunisian Commercial Banks According to the Intermediation Approach, Canadian Center of Science and Education, International Journal of Economics and Finance, 5 (5): 190-203.

[26] Garza-Garcia, J. G. (2011). Determinants of Bank Performance in Mexico: Efficiency or Market Power, Centre for Global Finance, Working Paper Series No 03, Bristol Business School, University of the West of England, United Kingdom.

[27] Gupta, V. K.and Aggarwal, M., (2012). Performance Analysis of Banks in India - Pre and Post World Trade Organization (General Agreement on Trade in Services), European Journal of Business and Management, 4 (3): 8-19.

[28] Guru, B. K., Staunton, J.and Shanmugam, B.(2000). Determinants of Commercial Bank Profitability in Malaysia, Avialable online at web.usm.my/aamj/, 17-06-2014.

[29] Hardy, D. C. and Patti, E. B. (2001). Bank Reform and Bank Efficiency in Pakistan, IMF Working Paper no 138, Available online at www.imf.org/external/pubs/ft/wp/2001/wp01138.pdf, 17-06-2014.

[30] Heffernan, S. and Fu M. (2008a). Bank Productivity Changes in Two Asian Giants, Social Science Research Network, Available at http://ssrn.com/abstracts, 09-05-2013.

[31] Heffernan, S. and Fu M. (2008b). The Determinants of Bank Performance in China, Available online at http://papers.ssrn.com/sol3/papers.cfm?abstract_id=1247713, 18-06-2014.

[32] Huang, W. (2010). Banking Sector Reforms and Commercial Bank Performance in China, Nottingham University Business School Conference Paper, Ningbo China, Available online at http://www.ceauk.org.uk/2010-conference-papers/full-papers, 19-06-2014.

[33] Iimi A, (2004). Efficiency in the Pakistani Banking Industry: Empirical Evidence after the Structural Reforms in the late 1990s, Pakistan Development Review, 42(1): 41-57.

[34] Ikpefan, O. A.(2010). The Impact of Bank Capitalization in the Performance of Ngerian Banking Industry (1986-2006), The Journal Of Commerce 4(1): 24-39.

[35] International Monetary Fund (2013).Nigeria: Financial Sector Stability Assessment, Publication Services, Washington, D.C., IMF Country Report No. 13/140, Available at www.imf.org, 10.03.2014.

[36] Isu, H. O. (1991). Preventing Bank Failures in Nigeria in the Coming Decades: Some Imperatives, Nigerian Financial Review, 4 (2) : 35 - 43.

[37] Jiang, C.(2008). Analysis of Bank Efficiency of Chinese Commercial Banks andthe Effects of Institutional Changes on Bank Efficiency, Unpublished Ph. D Thesis, Middlesex University, London, UK..

[38] Jiang, C. and Yao, S.(2010). Banking Reform and Efficiency in China: (1995-2008), University of Nottingham research paper 2010/2011series.
[39] Kamau, A. and Were, M. (2013). What Drives Banking Sector Performance in Kenya?. Global Business and Economics Research Journal, 2(4): 45-59.

[40] Keovongvichith, P. (2012). An Analysis of the Recent Financial Performance of the Laotian Banking Sector during 2005-2010, International Journal of Economics and Finance, 4 (4): 148-162.

[41] Kimera, N. S. (2011).Commercial Banks' Investment In Loans And Treasury Bills and their Overall Profitability In Uganda, Unpublished M. Sc. Dissertation, Makerere University, Uganda.

[42] Kiruri, R. M. (2013). The Effects of Ownership Structure on Bank Profitability in Kenya, European Journal of Management Sciences and Economics, 1(2): 116-127.

[43] Kumbirai, M. and Webb, R. (2010). A financial Ratio Analysis of Commercial Bank Performance in South Africa, African Review of Economics and Finance, 2(1): 30-53.

[44] Lin, C. and Kao, M. (2011). Does First Financial Reform in Taiwan Improve the Performance of Focused Financial Firms?, Available
centerforpbbefr.rutgers.edu/2011PBFEAM/, 13-05-2013.

[45] Lin, X. Zhang, Y. (2006). Bank ownership reform and bank performance in China, Journal of Banking \& Finance, 10(1016):1-10.

[46] Luo, D. (2009). Financial System and Reform of Chinese Commercial Banks, Unpublished Ph. D Thesis, University of Nottingham, England, United Kingdom.

[47] Mahesh H. P, and Bhide, S. (2008), "Do Financial Sector Reforms Make Commercial Banks More Efficient? A Parametric exploration of the Indian Case", The Journal of Applied Economic research. 2. (4): 416 -440. .

[48] Mlachila, M. amd Chirwa, E. W. (2002). Financial Reforms and Interest Rate Spreads in the Commercial Banking System in Malawi, IMF Working Paper no 6, Available online at www.imf.org/external/pubs/ft/wp/2002/wp016.pdf, 13-042013.

[49] Mogboyin, O., Asaolu, T. O. \& Ajilore, O. T. (2012). Bank Consolidation Programme and Lending Performance in Nigerian Banking System: An Empirical Analysis with Panel data, The International Journal of Applied Economics and Finance, 6(3): 100-108.

[50] Nawaz, M., Munir, S., Siddiqui, S. A., Ahad, T., Afzal, F., Asif, M. And Ateeq, M. (2012). Credit Risk And The Performance Of Nigerian Banks, Interdisciplinary Journal Of Contemporary Research In Business, 4 (7): 49-63.

[51] Ningi, S. I. and Dutse, A. Y.(2008). Impact of Bank Consolidation Strategy on the Nigerian Economy, African Economic and Business Review, 6(2): 26-45.

[52] Nzotta, S. M. and Okereke, E. J. (2009). Financial Deepening and Economic Development of Nigeria: An Empirical Investigation, African Journal of Accounting, Economics, Finance and Banking Research, 5(5): 52-66.

[53] Odeleye, A. T. (2014). Pre-Consolidation and PostConsolidation of Nigerian Banking Sector: A Dynamic Comparison, International Journal of Economics and Financial Issues, 4 (1): 27-34. 
[54] Ofanson, E.J., Aigbokhaevbolo, O. M., and Enabulu, G. O. (2010). The Financial System in Nigeria: An overview of Banking Sector Reforms, AAU JMS, 1 (1), 16-36.

[55] Ofoegbu, O. I. \& Iyewumi, A. T. (2013). Bank Consolidation and Deregulation Effects on the Level of Competition in the Nigerian Banking Industry, International Journal of Economic Policies and Theories, 3(1): 37-49.

[56] Oladele, P. O., Abosede, A. J. and Akeke, N. I. (2012). A PostConsolidation Assessment of Profitability in Nigerian Banks, Journal of Social and Development Sciences, 3(1): 1-5.

[57] Olajide, O. T., Asaolu, T and Jegede, C. A.(2011). The Impact of Financial Sector Reforms on Banks Performance in Nigeria, The International Journal of Business and Finance Research, 5(1): 53-63.

[58] Olaosebikan, B.(2009). Surveying Efficiencies of Nigerian Banks before and after the Minimum Capital Requirement Increase, Unpublished B.A. Thesis, llinois Wesleyan University, Bloomington, IIinois, United States of America.

[59] Ongore, V. O., and Kusa, G. B.(2013). Determinants of Financial Performance of Commercial Banks in Kenya, International Journal of Economics and Financial Issues, 3 (1): $237-252$.

[60] Rajeev, M .and Mahesh, H. P. (2010).Liberalization and Productive Efficiency of Indian Commercial Banks: A Stochastic Frontier Analysis, Nagarbhavi, Bangalore, Institute for Social and Economic Change, Available online at www.isec.ac.in/WP, 10-05-2013.

[61] Shah, D.(2007). Banking Sector Reforms and Co-operative Credit Institutions in Maharashtra: A Synthesis, Agricultural Economics Research Review, 20: 235-254.

[62] Shankar, R. and Sanyal,P. (2007). What Drives Bank Performance? An Analysis for the Post-Reform Period in India, Available online at http://people.brandeis.edu/ psanyal/, 1706-2014.

[63] Simpasa, A. M. (2013). Competition and Market Structure in the Zambian Banking Sector, African Development Bank, Working Paper No. 168.

[64] Uddin, S. M. S. and Suzuki, Y.(2011). Financial Reform, Ownership and Performance in Banking Industry: The Case of Bangladesh, International Journal of Business and Management, 6 (7): 28-39.

[65] Ukoha O. O. and Nwabuko, O. J. (2006). Impact of ADP Promotional Activities on Cassava Production: A Case Study of Ikwuano Local Government Area of Abia State, Nigeria, Journal of Applied Chemistry \& Agricultural Research, 9: 4450 .

[66] Wen, W.(2010). Ownership Structure and Banking Performance: New Evidence in China, Unpublished Ph. D Thesis, Autonomous University of Barcelona, Cerdanyola del Vallès, Barcelona, Spain. 